\title{
Phagocytic activity and the phagocytic index of milk PMN's as a marker for diagnosis and monitoring of the therapeutic and prophylactic efficacy of antioxidant formulation in bovine mastitis
}

\author{
Amatul Muhee, Hamidullah Malik, Riyaz A. Bhat*, Syed Taifa, Mehak N. B. Azad, \\ and Waseem Rather
}

Division of Clinical Veterinary Medicine, Ethics and Jurisprudence, Faculty of Veterinary Sciences and Animal Husbandry, Srinagar, Jammu and Kashmir, India

MUHEE, A., H. MALIK, R. A. BHAT, S. TAIFA, M. N. B. AZAD, W. RATHER: Phagocytic activity and the phagocytic index of milk PMN's as a marker for diagnosis and monitoring of the therapeutic and prophylactic efficacy of antioxidant formulation in bovine mastitis. Vet. arhiv 91, 227-236, 2021.

\section{ABSTRACT}

A clinical study was undertaken on bovine mastitis in the Kashmir valley to study the relationship between Phagocytic activity (PA) and the phagocytic index (PI) of milk neutrophils (PMN's) and bovine mastitis. The PA and PI of milk PMN's were assessed in mastitic animals and compared with normal, healthy, lactating animals. A significant decrease was found in the values of the PA and PI of milk neutrophils in clinical cases of mastitis as compared to the healthy control group. The utility of anti-oxidants in clinical management of mastitis was measured through the response to treatment with trace minerals such as $\mathrm{Cu}, \mathrm{Zn}, \mathrm{Mn}$ and $\mathrm{Se}$ in addition to conventional antibiotic therapy. Two groups of mastitic animals received two therapeutic regimens. Group I animals received antibiotics (Enrofloxacin $6.6 \mathrm{mg} / \mathrm{kg}$ BID for 5 days) and a self-formulated trace mineral anti-oxidant mixture at therapeutic doses for 7 days, while Group II animals only received the antibiotic (at the same dose rate and frequency). Therapeutic regimen I proved more efficacious than the therapeutic regimen II in the treatment of clinical mastitis, as evidenced by higher recovery rates, a lower number of mean days required for recovery, and higher PA and PI of the milk PMN's on day 10 post treatment. For prophylactic studies, 24 healthy lactating cows were divided into two groups of 12 animals each. One group was supplemented with a self-formulated trace mineral anti-oxidant mixture at prophylactic doses for 30 days, which resulted in a significant improvement in udder health status in terms of the SCC, PA and PI of milk PMN's. Supplementation with the antioxidant formulation played a significant role in early recovery and prophylaxis of bovine mastitis. Assessment of PA and PI of milk PMN's could be utilised as an effective tool for diagnosing susceptibility to the occurrence of mastitis, as well as monitoring the therapeutic efficacy of different treatment regimes.

Key words: bovine mastitis; milk PMN's; phagocytic activity; phagocytic index; anti-oxidant trace minerals

\footnotetext{
*Corresponding author:

Dr. Riyaz Ahmed Bhat, Division of Clinical Veterinary Medicine, Ethics and Jurisprudence, Faculty of Veterinary Sciences and Animal Husbandry, Srinagar-190006, Jammu and Kashmir, India, E-mail: koolriya22@gmail.com
} 


\section{Introduction}

Mastitis is a difficult problem to comprehend because of its multifactorial infectious nature. Its incidence depends on the microorganisms involved, the surrounding environment and the defense mechanisms in the udder tissues and blood. The mammary gland is protected by a variety of defense mechanisms, such as non-phagocytic and phagocytic defences (ATABAI et al., 2007: MEHRZAD et al., 2010). The phagocytic defence consists mainly of phagocytic cells in the mammary gland and those recruited in response to inflammatory reactions (PMNs/Neutrophils). Neutrophils form the integral part of mammary innate defense system during foreign intrusion of microbes as an early response of the host body (BORREGAARD, 2010). The ability of neutrophils to phagocytose foreign particles is important for protection of the mammary gland, and in vitro analysis of neutrophil function provides a very effective tool for the study of natural mastitis resistance (AL HUSSSEIN et al., 2015). It has been reported that the main reason for the increased susceptibility in dairy animals to mastitis is immune-suppression (MALLARD et al., 1998). Successful intramammary defence is dependent on an increase in PMN arriving at the site of infection and a high rate of phagocytosis (PAAPE et al., 2003). Any condition that depresses PMN functions adversely affects the udder's resistance to invasive infections (MEHRZAD et al., 2009). The increased incidence of severe mastitis during early lactation correlates with decreased blood and milk PMN (MEHRZAD et al., 2010), further emphasizing the pivotal role of PMN in the defence against intramammary pathogens. Phagocytic activity (PA) is the percentage of neutrophils that phagocytosed the target organisms in an in vitro condition, and the phagocytic index (PI) is calculated as the average number of target microorganism(s) phagocytosed per phagocyte. Although the phagocytic ability of the milk neutrophils in the mammary gland is lower than in other tissues, it still remains the most critical defense once the teat end barrier is breached. The circulating half-life of neutrophils is about 6 hours, so the cow replaces half of those cells every 6 hours from its bone marrow stores, and the circulating pool is largely dependent on the proliferative capacity of the bone marrow (KIMURA et al., 1999). Clearly, a significant component of the dietary energy and protein consumption for maintenance is spent on replenishment of immune cells. So, supplementing trace minerals and vitamins in greater quantity in and around parturition reduces both the duration and the severity of udder affections, and enhances udder immunity (WEISS, 2002). So the best way to treat mastitis is to give mastitic cows the best possible hygienic conditions and an appropriate diet. It has been proved that dietary supplementation with high levels of Vitamin E during the periparturient period substantially benefits udder health (BOUWSTRA et al., 2010) and enhances the chemotactic responsiveness of blood neutrophils (EICHER et al., 1994). Enhanced phagocytic activity and phagocytic index have also been reported in milk PMN cells in mastitic buffaloes treated with enrofloxacin, vitamin $\mathrm{E}$ and selenium (MUKHERJEE, 2008). Supplementation with antioxidants may prove an effective tool for protecting mammary tissue against PMN-induced oxidative stress during bovine mastitis, and in addition antioxidant supplementation may also help in preventing mastitis by strengthening the mammary defense system and improving immunity. So the present study was undertaken to study the effect of supplementation of anti-oxidant trace minerals on the clinical recovery, prophylaxis, and phagocytic activity and phagocytic index of milk PMN's in bovine mastitis. The role of the PA and PI of milk PMN's as diagnostic and prophylactic markers of bovine mastitis was also evaluated.

\section{Materials and methods}

The study was undertaken on clinical cases of bovine mastitis presented for treatment to the Teaching Veterinary Clinical Complex, F.V.Sc \& A.H, SKUAST-K and local animal husbandry dispensaries in the areas of Ganderbal, Manasbal, Shuhama, Gulab Bagh and Shalimar during the course of study.

A total of 36 multiparous cows in the 4-8 years age group with body condition score (BCS) 3.0, were included for the study. Twenty-four cows among them had clinical mastitis, 12 apparently healthy lactating animals served as a control group, 
and no experimental case was included. The cases of clinical mastitis were diagnosed on the basis of clinical examination, case history and clinical findings. The severity of the cases was assessed on the basis of CMT score and SCC of milk samples. Cases with a CMT score of 2 or 3, with somatic cell counts higher than $4 \times 10^{5} / \mathrm{mL}$ of milk were considered positive for mastitis.

For performing therapeutic trials, the mastitic animals were diagnosed by clinical presentation, CMT score and SCC, and were further divided into two groups of twelve animals each. The animals in group I were given a self-formulated anti-oxidant trace mineral mixture at therapeutic doses, as recommended by NRC, 2001, whose formulation is given in Appendix 1. All four ingredients were mixed together, making a total weight of about $5.005 \mathrm{~g}$, and stored in air-tight, zip lock, polyethene pouches. A total of 7 pouches were given to individual animal owners so they could provide the contents of one pouch to the animals once daily for 7 days. Group II animals were not given any anti-oxidant trace mineral mixture. Both the groups of animals were given the antibiotic enrofloxacin at the dose rate of $6.6 \mathrm{mg} / \mathrm{kg} \mathrm{i} / \mathrm{m}$ per animal, twice daily for 5 days. The choice of the antibiotic was based on an antibiotic sensitivity test of the milk, which was performed in each case. Animals found to be insensitive to enrofloxacin were excluded from the study. The therapeutic trial design for the cows with clinical mastitis is provided in Table 1.
For the prophylactic study, 24 recently parturiated, lactating animals maintained at the Mountain Livestock Research Institute (MLRI), SKUAST-K, Manasbal, undersimilarmanagemental conditions, but with susceptibility to occurrence of mastitis (as evidenced by precedence to occurrence of mastitis in previous lactations) were selected. One group of animals (Group I) comprised of 12 animals, received a self-formulated anti-oxidant trace mineral mixture for a period of thirty days, while Group II also comprised of 12 animals did not receive any anti-oxidants. The anti-oxidant trace minerals were given at prophylactic doses as recommended by NRC, 2001. The composition of the anti-oxidant trace mineral mixture is given in Appendix I. The total dose per animal was 1.402 grams. Three hundred and sixty pouches were made, and one pouch per animal per day was given to Group I animals for 30 days.

The efficacy of the prophylactic treatment was evaluated by registering the occurrence of mastitis during the course of the therapy and one month after therapy. The udder health status of both the groups of animals was assessed on the basis of an estimation of the SCC of the milk, phagocytic activity and the phagocytic index of the milk PMN's day 0, day 15 and day 30 of treatment, and fifteen days after the end of the treatment. Both groups of animals were monitored for the occurrence of mastitis for a period of one month after the end of the therapy.

Table 1. Therapeutic trial design for cows with clinical mastitis

\begin{tabular}{|l|c|c|c|c|c|c|}
\hline Group & $\begin{array}{c}\text { No. of animals } \\
\text { treated }\end{array}$ & Treatment & Dosage & Route & Frequency & Duration of treatment \\
\hline $\begin{array}{l}\text { Group I } \\
\text { (Therapeutic } \\
\text { regime I) }\end{array}$ & 12 & Inj. Enrofloxacin & $6.6 \mathrm{mg} / \mathrm{kg}$ & $\mathrm{I} / \mathrm{M}$ & $\mathrm{BID}$ & 5 days \\
\cline { 2 - 7 } & $\begin{array}{c}\text { Anti-oxidant trace } \\
\text { mineral mixture }\end{array}$ & $5.005 \mathrm{gms}$ & Oral & OD & 7 days \\
\hline $\begin{array}{l}\text { Group II } \\
\text { (Therapeutic } \\
\text { regime II) }\end{array}$ & 12 & Inj. Enrofloxacin & $6.6 \mathrm{mg} / \mathrm{kg}$ & $\mathrm{I} / \mathrm{M}$ & BID & 5 days \\
\hline
\end{tabular}


The phagocytic activity of the milk PMN's was estimated from the milk of healthy lactating cows as well as from clinical cases of mastitis on day 0 , day 5 and day 10 of treatment and for prophylactic studies on day 0 , day 15 and day 30 of treatment. The in vitro phagocytosis activity of milk neutrophils (PMN) was determined on Staphylococcus aureus. The procedure was performed in the following manner:

Isolation of milk PMN's. A total of $50 \mathrm{~mL}$ of milk was passed through cheese cloth and then poured into $50 \mathrm{~mL}$ conical tubes and centrifuged in a cooling centrifuge at $1200 \mathrm{~g}$ or $2942 \mathrm{rpm}$ (approximately 3000) at $4{ }^{\circ} \mathrm{C}$. The fat was removed and the skim milk was poured off and discarded. The cell pellet was washed twice in cold Dulbecco's PBS and centrifuged at $300 \mathrm{~g}$ for 10 minutes and $200 \mathrm{~g}$ for 15 minutes at $4{ }^{\circ} \mathrm{C}$ and resuspended in Dulbecco's PBS containing $0.5 \mathrm{mg} / \mathrm{mL}$ gelatin. In a $15 \mathrm{~mL}$ falcon, $3 \mathrm{~mL}$ of Histopaque 1119 (Sigma Aldrich, USA) was taken, over which $3 \mathrm{~mL}$ of Histopaque 1077 (Sigma Aldrich, USA) was layered slowly so as to form a ring at the junction of the two histopaques. Three $\mathrm{mL}$ of cell suspension was layered slowly over the Histopaque 1077 . The tube was gently placed into the centrifuge and centrifugation was carried out at $2000 \mathrm{~g}$ at $4{ }^{\circ} \mathrm{C}$ for 30 minutes. The cell pellet formed at the interface between the Histopaque 1119 and 1077 was taken as the milk PMN's. The collected cells were washed twice with PBS and resuspended in RPMI medium containing 10\% fetal calf serum for further analysis, and they served as the source of milk PMN's. The viability of milk PMN's was checked by the trypan blue exclusion technique, and the final cell concentration was adjusted to $1 \times 10^{6} \mathrm{cells} / \mathrm{ml}$.

Viable cell count of milk leukocytes. Before the cells had the chance to settle, $0.5 \mathrm{~mL}$ of cell suspension was transferred into an Eppendorf tube. $100 \mu \mathrm{L}$ of cells were transferred into a new Eppendorf tube, $400 \mu \mathrm{L}$ of $0.4 \%$ trypan blue was added and gently mixed. One hundred $\mu \mathrm{L}$ of trypan blue treated cells were loaded onto a haemocytometer. The viable (unstained) cells were counted in all the four sets of 16 corners (WBC counting chambers).Viable cell count was expressed as:
Viable cell count $=$ Average count in 4 squares $\times$ Dilution factor $\times 10^{4}$

$\%$ Viability $=$ All live and dead cells were added to obtain the total cell count. The live cell count was divided by the total cell count to calculate the viability percentage.

Dilution factor $=5$

Viability of all the samples was more than $90 \%$.

Adjustment of cell numbers. The concentration in the cell suspension was adjusted to $2.5 \times 10^{6} \mathrm{cell} / \mathrm{s} / \mathrm{mL}$.

$\mathrm{X} \mathrm{mL}$ of RPMI added $=\frac{\text { No. of viable cells per } \mathrm{mL}}{2.5 \times 10^{6}}$

(e.g., if the viable cell count was $5 \times 10^{6}, \mathrm{X}-1$ $\mathrm{mL}$ of RPMI i.e. $2-1=1 \mathrm{~mL}$ of RPMI was added to $\mathrm{PMN}$ suspension to reach a concentration of $2.5 \times 10^{6}$ cells $/ \mathrm{mL}$ ).

Phagocytic activity and phagocytic index. Bacterial concentration of 18 hour culture of pure Staphylococcus aureus (MTCC, Chandigarh) was adjusted to $2 \times 10^{8} \mathrm{cfu} / \mathrm{mL}$ by checking optical density (OD) at $540 \mathrm{~nm}$ under a UV spectrophotometer (OD was adjusted to 0.6 with PBS). For phagocytosis assay, $0.1 \mathrm{~mL}$ of the bacterial suspension was opsonised with $0.1 \mathrm{~mL}$ of pooled bovine serum in an incubator at $37^{\circ} \mathrm{C}$ for 1 hour, in a tissue culture plate. Then $0.8 \mathrm{~mL}$ of PMN suspension was added and incubated at $37{ }^{\circ} \mathrm{C}$ for 30 minutes to maintain the PMN's and bacteria in a ratio of 1:10. Smears were prepared and stained with Leishman stain. The slides were then examined under a high power microscope at $\times 1000$ magnification.

PA (phagocytosis percentage) was estimated as the percentage of cells that took part in phagocytosis

$$
\text { Phagocytic activity }=\frac{\begin{array}{l}
\text { No. of PMN that } \\
\text { engulfed bacteria }
\end{array}}{\text { No. of PMN counted }} \times 100
$$

Phagocytic index (PI) was estimated as the mean of the total bacteria counted phagocytosed per neutrophil.

Phagocytic index $=\frac{\text { Total bacteria in N neutrophil }}{\mathrm{N}}$

There was 25 neutrophils counted 25 , so here $\mathrm{N}=25$. 
A. Muhee et al.: Phagocytic activity and the phagocytic index of milk PMN's as a marker for diagnosis and monitoring of the therapeutic and prophylactic efficacy of antioxidant formulation in bovine mastitis

The result of PA was reported as the percentage (\%) of phagocytosing neutrophils counting 100 PMN cells in different microscope fields, and the result of PI was reported as the average number of bacteria per neutrophil.

Statistical analysis. The data was analysed using statistical tools (SPSS version 20). ANOVA followed by Duncan's multiple range test were used for multiple comparisons. The paired ' $t$ ' test was used for pre- and post-treatment comparisons within each treatment group. Repeated measure ANOVA was used for multiple pre- and posttreatmentcomparisons. Statistical differences were determined at the level of 5\% significance.

\section{Results}

Phagocytic activity and the phagocytic index of milk neutrophils or PMN's. The phagocytic activity (PA) and phagocytic index (PI) of milk neutrophils or PMN's in the healthy control group and in animals with clinical mastitis (mastitic group) is presented in Table 2. The effect of the different therapeutic regimens (I \& II) on the phagocytic activity and phagocytic index of milk neutrophils in the two groups of mastitic animals (Group I and Group II) is presented in Table 3. The mean values for the phagocytic activity of milk neutrophils (\%) in the healthy control group of animals (35.42 \pm 1.27) was significantly higher $(\mathrm{P}<0.05)$ than that of the mastitic group values $(18.30 \pm 0.46)$, as shown in Table 2. The mean values for the phagocytic activity of neutrophils (\%) in group I animals with clinical mastitis were $18.13 \pm 0.58,23.07 \pm 0.78$ and $33.47 \pm 1.08$ on day 0 , day 5 and day 10 of receiving therapeutic regimen I, respectively (Table 3).
The mean values of the phagocytic activity of milk neutrophils (\%) on days 0,5 and 10 of treatment within group I mastitic animals differed significantly from each other $(\mathrm{P}<0.05)$. In group II animals with clinical mastitis, the mean values of the phagocytic activity of milk neutrophils (\%) on days 0,5 and 10 of treatment with therapeutic regimen II were $18.5 \pm 0.76,24 \pm 0.95$ and 28.25 \pm 0.83 , respectively, and also differed significantly $(\mathrm{P}<0.05)$ from each other (Table 3$)$. The mean value of PI in the healthy control group was 6.82 \pm 0.16 , while in mastitic group the mean value was $3.64 \pm 0.10$ (Table 2). The difference in the mean values of PI between the healthy control group and the mastitic group was statistically significant $(\mathrm{P}<0.05)$. The mean values for the PI of neutrophils in group I animals with clinical mastitis were 3.65 $\pm 0.14,5.33 \pm 0.14$ and $6.26 \pm 0.07$ on days 0 , day 5 and day 10 of treatment, respectively, and the mean values of the phagocytic index of neutrophils on days 0,5 and 10 of treatment within this group of mastitic animals differed significantly $(\mathrm{P}<0.05 \%)$ from each other (Table 3). In group II animals with clinical mastitis the mean values were $3.62 \pm 0.16$, $4.86 \pm 0.17$ and $5.79 \pm 0.20$ on day 0 , day 5 and day 10 of treatment, respectively, and the mean values of the phagocytic index of neutrophils on days 0 , 5 and 10 within this group of animals also differed significantly $(\mathrm{P}<0.05 \%)$ from each other (Table 3$)$.

Recovery of animals. In group I animals, ten animals recovered within a mean $4 \pm 0.5$ days, as evidenced by clinical recovery (CMT negative), and the return of milk SCC and milk chemistry parameters to normal.

Table 2. Comparison of Phagocytic activity (PA) and Phagocytic Index (PI) between healthy lactating (control group) and mastitic animals

\begin{tabular}{|l|c|c|}
\hline Parameters & $\begin{array}{c}\text { Control Group } \\
(\mathrm{n}=12)\end{array}$ & $\begin{array}{c}\text { Mastitic Group } \\
(\mathrm{n}=24)\end{array}$ \\
\hline Phagocytic Activity (\%) & $35.42 \pm 1.27^{\mathrm{a}}$ & $18.30 \pm 0.46^{\mathrm{b}}$ \\
\hline $\begin{array}{l}\text { Phagocytic Index (average No. of bacteria phagocytosed } \\
\text { per phagocyte) }\end{array}$ & $6.82 \pm 0.16^{\mathrm{a}}$ & $3.64 \pm 0.10^{\mathrm{b}}$ \\
\hline
\end{tabular}

Values within a row with a superscript $(\mathrm{a}, \mathrm{b})$ with at least one common letter do not differ significantly at the level of $5 \%(\mathrm{P}<0.05)$ from each other 
A. Muhee et al.: Phagocytic activity and the phagocytic index of milk PMN's as a marker for diagnosis and monitoring of the therapeutic and prophylactic efficacy of antioxidant formulation in bovine mastitis

Table 3. Effect of treatment on Phagocytic Activity (PA) and Phagocytic Index (PI) in animals with clinical mastitis

\begin{tabular}{|l|c|c|c|}
\hline \multirow{2}{*}{ Parameters } & Days of treatment & $\begin{array}{c}\text { Group I (Antibiotic }+ \\
\text { Antioxidant trace minerals) }\end{array}$ & Group II (Antibiotic only) \\
\hline \multirow{2}{*}{$\begin{array}{l}\text { Phagocytic Activity } \\
(\%)\end{array}$} & Day 0 & $18.13 \pm 0.58^{\mathrm{a}}$ & $18.50 \pm 0.77^{\mathrm{a}}$ \\
\cline { 2 - 4 } & Day 5 & $23.07 \pm 0.78^{\mathrm{b}}$ & $24.00 \pm 0.96^{\mathrm{b}}$ \\
\cline { 2 - 4 } $\begin{array}{l}\text { Phagocytic Index } \\
\text { (Average No. of } \\
\begin{array}{l}\text { bacteria phagocytosed } \\
\text { per phagocyte) }\end{array}\end{array}$ & Day 10 & $33.47 \pm 1.08^{\mathrm{c}}$ & $28.25 \pm 0.83^{\mathrm{c}}$ \\
\cline { 2 - 4 } & Day 0 & $3.65 \pm 0.14^{\mathrm{a}}$ & $3.62 \pm 0.16^{\mathrm{a}}$ \\
\cline { 2 - 4 } & Day 5 10 & $5.33 \pm 0.14^{\mathrm{b}} \pm 0.17^{\mathrm{b}}$ \\
\hline
\end{tabular}

Values within a column having superscript $(\mathrm{a}, \mathrm{b}, \mathrm{c})$ with at least one common letter do not differ significantly at the level of $5 \%$ $(\mathrm{P}<0.05)$ from each other.

Table 4. Therapeutic efficacy of treatment regimes in animals with clinical mastitis

\begin{tabular}{|l|c|c|}
\hline & Group I & Group II \\
\hline Animals treated & 12 & 12 \\
\hline Animals recovered & 10 & 8 \\
\hline$\%$ Recovery & $83.33 \%$ & $66.66 \%$ \\
\hline Recovery time (Days \pm S.E) & $4 \pm 0.5$ & $4.5 \pm 0.8$ \\
\hline
\end{tabular}

Table 5. Impact of prophylactic anti-oxidant trace mineral therapy on udder health status of healthy lactating animals during treatment

\begin{tabular}{|l|c|c|c|}
\hline \multirow{4}{*}{ Parameters } & Days of treatment & $\begin{array}{c}\text { Group I } \\
\text { (With anti-oxidants) }\end{array}$ & $\begin{array}{c}\text { Group II } \\
\text { (Without anti-oxidants) }\end{array}$ \\
\hline \multirow{3}{*}{ SCC $\left(\times 10^{5} / \mathrm{mL}\right)$} & Day 0 & $2.81 \pm 0.07^{\mathrm{a} 1}$ & $2.81 \pm 0.06^{\mathrm{a} 1}$ \\
\hline \multirow{3}{*}{\begin{tabular}{l} 
Phagocytic Activity (\%) \\
\cline { 2 - 4 }
\end{tabular}} & Day 15 & $2.65 \pm 0.06^{\mathrm{a} 1}$ & $2.77 \pm 0.06^{\mathrm{a} 1,2}$ \\
\cline { 2 - 4 } & Day 30 & $2.48 \pm 0.03^{\mathrm{a} 2}$ & $2.97 \pm 0.07^{\mathrm{b} 2}$ \\
\hline \multirow{3}{*}{$\begin{array}{l}\text { Phagocytic Index (Average No. of } \\
\text { bacteria phagocytosed per phagocyte) }\end{array}$} & Day 0 & $28.13 \pm 0.58^{\mathrm{a} 1}$ & $28.50 \pm 0.77^{\mathrm{a} 1}$ \\
\cline { 2 - 4 } & Day 15 & $31.07 \pm 0.78^{\mathrm{a} 2}$ & $24.00 \pm 0.96^{\mathrm{b} 2}$ \\
\cline { 2 - 4 } & Day 30 & $35.47 \pm 1.08^{\mathrm{a} 3}$ & $28.25 \pm 0.83^{\mathrm{b} 1,3}$ \\
\cline { 2 - 4 } & Day 0 & $5.83 \pm 0.14^{\mathrm{a} 2}$ & $4.06 \pm 0.17^{\mathrm{b} 2}$ \\
\hline
\end{tabular}

Values within a row with a superscript $(\mathrm{a}, \mathrm{b})$ with at least one common letter do not differ significantly at the level of $5 \%(\mathrm{P}<0.05)$ from each other. Values within a column with a $(1,2,3)$ with at least one common number do not differ significantly at the level of $5 \%(\mathrm{P}<0.05)$ from each other. 
A. Muhee et al.: Phagocytic activity and the phagocytic index of milk PMN's as a marker for diagnosis and monitoring of the therapeutic and prophylactic efficacy of antioxidant formulation in bovine mastitis

Table 6. Impact of prophylactic anti-oxidant trace mineral therapy on the udder health status of healthy lactating animals 15 days after stopping the therapy

\begin{tabular}{|l|c|c|}
\hline Parameter & Group I (With anti-oxidants) & Group II (Without anti-oxidants) \\
\hline SCC $\left(\times 10^{5} / \mathrm{mL}\right)$ & $2.72 \pm 0.09^{\mathrm{a}}$ & $3.07 \pm 0.06^{\mathrm{b}}$ \\
\hline Phagocytic Activity $(\%)$ & $38.40 \pm 1.25^{\mathrm{a}}$ & $29.90 \pm 0.72^{\mathrm{b}}$ \\
\hline $\begin{array}{l}\text { Phagocytic Index(Average No. of } \\
\text { bacteria phagocytosed per phagocyte) }\end{array}$ & $7.26 \pm 0.09^{\mathrm{a}}$ & $5.57 \pm 0.19^{\mathrm{b}}$ \\
\hline
\end{tabular}

Values within a row with a superscript $(\mathrm{a}, \mathrm{b})$ with at least one common letter do not differ significantly at the level of $5 \%(\mathrm{P}<0.05)$ from each other.

APPENDIX -I: Therapeutic dose of mineral mixture:

Copper sulphate: $1 \mathrm{gm}$.

Zinc sulphate: 2 gm.

Manganese sulphate: $2 \mathrm{gm}$

Selenium: $\quad 5 \mathrm{mg}$

Total Dose: $\quad 5.005 \mathrm{~g} / \mathrm{animal} / \mathrm{day}$ for 7 days

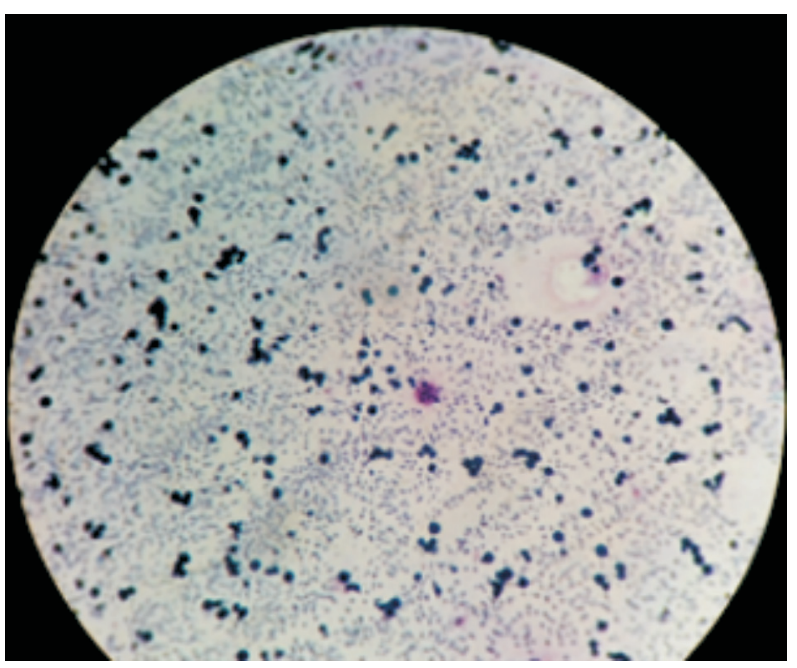

Fig. 1.Phagocytic activity of milk PMN's

The percentage recovery was $83.33 \%$. Group II animals were not given any mineral mixture. In this group of animals, 12 animals were treated, of which 8 animals recovered completely within a mean 4.5 \pm 0.8 days, as evidenced by clinical recovery (CMT negative) and the return of milk SCC and milk biochemical parameters to normal. The percentage recovery was $66.66 \%$.

Prophylactic studies. The udder health status of both groups of animals was monitored through estimation of the somatic cell count and phagocytic activity, and the phagocytic index of neutrophils on
Appendix -II: Prophylactic dose of mineral mixture:

Copper sulphate $\quad: 500 \mathrm{mg}$

Zinc sulphate : $500 \mathrm{mg}$

Manganese sulphate: $400 \mathrm{mg}$

Selenium $\quad: 2 \mathrm{mg}$

Total Dose $\quad: 1.042 \mathrm{~g} / \mathrm{animal} /$ day for 30 days

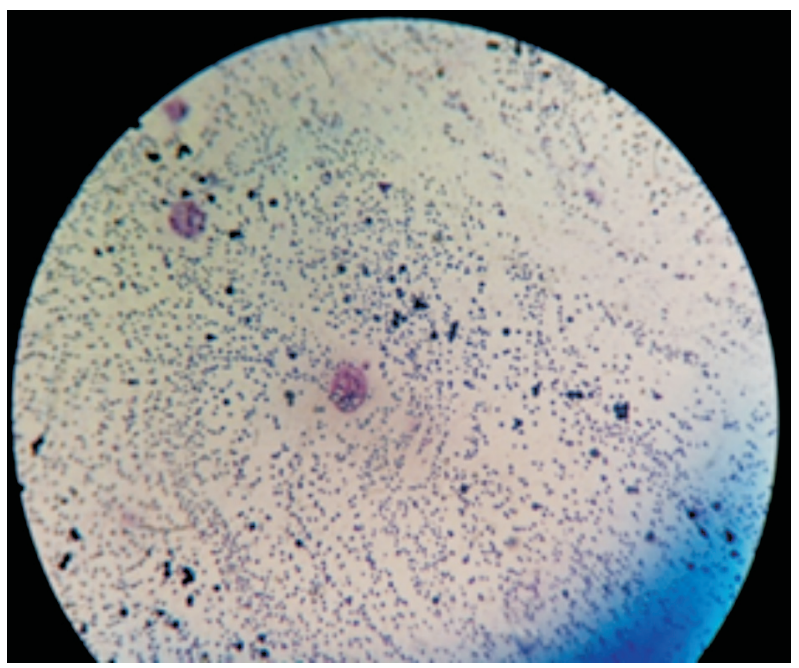

Fig. 2. Phagocytic index of milk PMN's

days 0,15 and 30 during the course of treatment, as well as 15 days after the end of the treatment (Tables 5 and 6). The animals were monitored for 15 more days, i.e. for a total period of one month after stopping the treatment, for occurrence of mastitis. Milk SCC was lower and the phagocytic activity of the milk PMN's was significantly higher in the group I animals as compared to group II animals, as shown in Tables 5 and 6. Clinical mastitis was not observed in any of the animals in the two groups of animals, either during the course of treatment or one month after the study. 


\section{Discussion}

Phagocytic activity and phagocytic index of milk neutrophils or PMN's. Our findings of decreased phagocytic activity and lower phagocytic index in clinical mastitis are in agreement with the findings of AL-HUSSEIN et al. (2015), who also reported a significant decrease in phagocytic activity of milk PMN's in cows with clinical and sub-clinical mastitis. Our findings are also in agreement with DE UK and MUKHERJEE (2013), who also found that the PA of milk leukocytes was lower in mastitic cows, whereas, a significant enhancement in PA was recorded in post-treated cows. PICCININI et al. (1999) also reported depressed milk PMN phagocytic activity associated with intramammary infection by $S$. aureus.

Recovery of animals. Our findings of increased recovery in group I animals are supported by the fact that dairy cows supplemented with a combination of anti-oxidant trace elements ( $\mathrm{Se}, \mathrm{Cu}$, $\mathrm{Zn}$ and $\mathrm{Mn}$ ) in therapeutic regimen I $v s$. therapeutic regimen II showed better recovery rates $(83.33 \%$ vs $66.66 \%$ ), a shorter recovery time ( $4 \pm 0.5$ days $v s$. $4.5 \pm 0.8$ days) with higher phagocytic activity and phagocytic index of the milk PMN's. Our findings of increased recovery rates through the use of antioxidant trace mineral supplementation is supported by the findings of MACHADO et al. (2013).YANG and LI (2015) also reported that supplementation of mastitic dairy cows with antioxidant vitamins such as vitamin $\mathrm{A}, \mathrm{C}, \mathrm{E}$ and $\beta$-carotene, and antioxidant minerals such as selenium, zinc and copper was very important to help the animals recover early.

Prophylactic studies. The udder health status of group I animals was found to be better than group II as evidenced by a significant increase in phagocytic activity and the phagocytic index of their milk PMN's, and the significant decrease in milk SCC count during the course of treatment and 15 days after the end of treatment (Tables 5 and 6), indicating the increased capability of the udders to defend themselves against the attack of the pathogenic microorganisms responsible for causing mastitis, and hence the decreased susceptibility to the occurrence of mastitis in this group as compared to the control group. Our findings are in agreement with MACHADO et al. (2013) who reported that dairy cows supplemented with a combination of different trace elements ( $\mathrm{Se}, \mathrm{Cu}$, $\mathrm{Zn}$ and $\mathrm{Mn}$ ) showed lower SCC levels (decreased incidence of mastitis) in comparison to the control cows. SORDILLO and MAVANGIRA (2014) also advocated controlling mastitis through appropriate antioxidant supplementation in the form of trace mineral supplementation that could potentially boost the animals' health status and performance.

\section{Conclusion}

Since the present study revealed significantly lower PA and PI of milk PMN's in clinical mastitis, which subsequently increased with supplementation of an antioxidant mineral formulation, estimation of the PA and PI of milk PMN's may prove to be an effective biomarker for detecting susceptibility to the occurrence of bovine mastitis, and monitoring the therapeutic efficacy of treatment regimes. Antioxidant trace minerals such as $\mathrm{Cu}, \mathrm{Zn}, \mathrm{Mn}$ and Se significantly increase the PA and PI of milk PMN's, and thereby aid early recovery from bovine mastitis and play a significant role in prophylaxis of mastitis in lactating animals. This study strongly supports the hypothesis that boosting the PA and PI of milk PMN's through supplementation with an antioxidant mineral mixture could prove an effective strategy to prevent and reduce the severity of bovine mastitis.

\section{Acknowledgment}

The authors are highly thankful to FVSc and AH, Shuhama for providing the necessary facilities for this research work.

\section{Conflict of interest}

The authors declare that there is no conflict of interest for this study.

\section{References}

AL HUSSEIN, M., M. KAUR, P. MANJARI, S. P. KIMOTHI, A. K. MOHANTY, A. K. DANG (2015): A comparative study on the blood and milk cell counts of healthy, subclinical, and clinical mastitis Karan Fries cows. Vet. World 8, 685-689.

DOI: $10.14202 /$ vetworld.2015.685-689

ATABAI, K., D. SHEPPARD, Z. WERB (2007): Roles of the innate immune system in mammary gland remodeling during involution. J. Mammary Gland Biol. Neoplasia 12, 37- 45. DOI: $10.1007 /$ s10911-007-9036-6 
A. Muhee et al.: Phagocytic activity and the phagocytic index of milk PMN's as a marker for diagnosis and monitoring of the therapeutic and prophylactic efficacy of antioxidant formulation in bovine mastitis

BORREGAARD, N. (2010): Neutrophils, from marrow to microbes. Immunity 33, 657-670.

BOUWSTRA, R. J., M. NIELEN, J. A. STEGEMAN, P. DOBBELAAR, J. R. NEWBOLD, E. H. J. M. JANSEN, T. VAN WERVEN (2010): Vitamin E supplementation during the dry period in dairy cattle. Part I: Adverse effect on incidence of mastitis postpartum in a double-blind randomized field trial. J. Dairy Sci. 93, 5684-5695.

DOI: $10.3168 /$ jds.2010-3159

DE UK, R. MUKHERJEE (2013): Dynamics of milk leukocytes in response to a biological response modifier during bovine subclinical mastitis. Res.Vet. Sci. 95, 352-357.

DOI: $10.1016 /$ j.rvsc.2013.06.010

EICHER, S. D., L. J. L. MORREIL, I. BLECHA (1994): Vitamin concentration and function of leukocyte from dairy calves supplemented with vitamin A, vitamin E and beta carotene in vitro. J. Dairy Sci. 77, 560-565.

DOI: $10.3168 /$ jds.s0022-0302(94)76984-8

KIMURA, K., J. P. GOFF, M. E. KEHRLI (1999): Effects of the presence of the mammary gland on expression of neutrophil adhesion molecules and myeloperoxidase activity in periparturient dairy cows. J. Dairy Sci. 82. 23852392.

DOI: 10.3168/jds.s0022-0302(99)75489-5

MACHADO, V. S., M. L. S BICALHO, R. V. PEREIRA, L. S. CAIXETA, W. A. KNAUER, G. OIKONOMOU, R. O. GILBERT, R. C. BICALHO (2013): Effect of an injectable trace mineral supplement containing selenium, copper, zinc, and manganese on the health and production of lactating Holstein cows. Vet. J. 197, 451-456.

DOI: $10.1016 /$ j.tvj1.2013.02.022

MALLARD, B. A., J. C. DEKKERS, M. J. IRELAND, K. E. LESLIE, S. SHARIF, C. LACEY VANKAMPEN, L. WAGTER, B. N. WILKIE (1998): Alteration in immune responsiveness during the periparturient period and its ramification on dairy cow and calf health. J. Dairy Sci. 81, 585-595.
DOI: $10.3168 /$ jds.s0022-0302(98)75612-7

MEHRZAD, J., L. DUCHATEAU, C. BURVENICH (2009): Phagocytic and bactericidal activity of blood and milkresident neutrophils against Staphylococcus aureus in primiparous and multiparous cows during early lactation. Vet. Microbiol. 134, 106-112.

DOI: 10.1016/j.vetmic.2008.09.001

MEHRZAD, J., M. PAAPE, C. BURVENICH (2010): Role of neutrophils in protection of udder from infection in high yielding dairy cows. Iran. J. Vet. Res. 11, 102-118.

MUKHERJEE, R. (2008): Selenium and vitamin E increases polymorphonuclear cell phagocytosis and antioxidant levels during acute mastitis in riverine buffaloes. Vet. Res. Commun. 32, 305-313.

DOI: $10.1007 / \mathrm{s} 11259-007-9031-9$

NRC (NATIONAL RESEARCH COUNCIL) (2001): Nutrient requirements of dairy cattle, National Academy Press, Washington DC.

PAAPE, M. J., D. D. BANNERMAN, X. ZHAO, J. W. LEE (2003): The bovine neutrophil: Structure and function in blood and milk. Vet. Res. 34, 597-627.

PICCININI, R., V. BRONZO, P. MORONI, C. LUZZAGO, A. ZECCONI (1999): Study on the relationship between milk immune factors and Staphylococcus aureus intramammary infections in dairy cows. J. Dairy Sci. 66, 501- 510.

DOI: $10.1017 / \mathrm{s} 0022029999003751$

SORDILLO, L. M., V. MAVANGIRA (2014): The nexus between nutrient metabolism, oxidative stress and inflammation in transition cows. Anim. Prod. Sci. 54, 1204-1214.

DOI: $10.1071 /$ an14503

WEISS, W. P (2002): Relationship of mineral and vitamin supplementation with mastitis and milk quality. National Mastitis Council Annual Meeting Proceedings, 37-44.

YANG, F. L., X. S. LI (2015): Role of antioxidant vitamins and trace elements in mastitis in dairy cows. Journal of Advanced Veterinary Animal Research 2, 1-9.

DOI: $10.5455 /$ javar.2015.b48

Received: 16 May 2020

Accepted: 5 June 2020

\section{MUHEE, A., H. MALIK, R. A. BHAT, S. TAIFA, M. N. B. AZAD, W. RATHER: Fagocitna aktivnost i fagocitni indeksi polimorfonuklearnih stanica mlijeka (PMN) kao markeri za dijagnozu i praćenje terapijske i profilaktičke učinkovitosti različitih formulacija antioksidanata u suzbijanju mastitisa goveda. Vet. arhiv 91, 227-236, 2021.}

\section{SAŽETAK}

Kliničko istraživanje mastitisa goveda u dolini Kashmir provedeno je kako bi se procijenila povezanost fagocitne aktivnosti (PA) i fagocitnih indeksa (PI) neutrofila u mlijeku (PMN's) i mastitisa goveda. PA i PI neutrofila u mlijeku analizirani su u životinja s mastitisom i uspoređeni sa zdravim životinjama u laktaciji. Pronađeno je znakovito smanjenje PA i PI neutrofila u mlijeku u slučajevima kliničkog mastitisa u usporedbi s kontrolnom, zdravom skupinom. Korisnost 
antioksidansa u slučajevima kliničkog mastitisa mjerena je putem odgovora na liječenje mineralima u tragovima kao što su $\mathrm{Cu}, \mathrm{Zn}, \mathrm{Mn}$ i Se, koji su dodani konvencionalnoj antibiotskoj terapiji. Dvije skupine životinja s mastitisom imale su dva terapijska programa. Skupina 1 primala je antibiotik (enrofloksacin 6,6 mg/kg, 2 puta dnevno, tijekom 5 dana) i vlastito pripremljenu mješavinu antioksidantnih minerala u tragovima u terapijskoj dozi tijekom 7 dana, dok je skupina 2 dobivala samo antibiotike (u istoj dozi i intervalu). Terapijski program u skupini 1 pokazao se učinkovitijim od onoga u skupini 2 u liječenju kliničkog mastitisa, što dokazuju veće stope oporavka, manji prosječan broj dana potreban za oporavak te povećane vrijednosti PA i PI polimorfonuklearnih stanica mlijeka deseti dan poslije tretmana. Za istraživanje profilakse 24 zdrave krave u laktaciji podijeljene su u dvije skupine sa po 12 životinja. Jedna je skupina dobivala vlastito pripremljenu mješavinu antioksidantnih minerala u tragovima u profilaktičkoj dozi tijekom 30 dana. To je rezultiralo znakovitim poboljšanjem zdravlja vimena što se vidjelo po vrijednostima SCC, PA i PI neutrofila u mlijeku. Dodatak antioksidantne formulacije znakovito je utjecao na rani oporavak i profilaksu mastitisa u goveda. Procjena PA i PI polimorfonuklearnih stanica mlijeka mogla bi biti učinkovit alat pri dijagnostici sumnje na mastitis kao i praćenju učinkovitosti različitih terapijskih program.

Ključne riječi: mastitis goveda; polimorfonuklearne stanice mlijeka; fagocitna aktivnost; fagocitni indeksi; antioksidantni minerali u tragovima 